\title{
Prevalence and risk factors for leishmaniasis and Chagas disease in the canine population of the tourist city of Ibiúna, São Paulo, Brazil
}

\author{
Prevalência e fatores de risco para leishmaniose e doença de \\ Chagas na população canina da Estância Turística de Ibiúna, \\ São Paulo, Brasil
}

\author{
Roberta Mascolli ${ }^{1}$; Francisco Rafael Martins Soto ${ }^{2}$; Sônia Regina Pinheiro ${ }^{3}$; \\ Fumio Honma Ito ${ }^{3}$; Aline Gil'; Sérgio Santos de Azevedo ${ }^{5}$; \\ Valéria Marçal Félix de Lima ${ }^{6}$; Hélio Langoni ${ }^{7}$; \\ Annielle Regina da Fonseca Fernandes ${ }^{8}$; Silvio Arruda Vasconcellos ${ }^{3 *}$
}

\begin{abstract}
The aims of the study were to determine the seroprevalence of leishmaniasis and Chagas disease, and to determine the risk factors associated with seropositivity in dogs in the tourist city of Ibiúna, São Paulo, Brazil. A total of 570 blood samples of dogs were collected from four regions in the 48 districts of the municipality, from September 2007 to March 2008, and submitted for serological examination. Laboratory diagnosis of leishmaniasis and Chagas disease was performed using indirect enzyme-linked immunosorbent assay and indirect immunofluorescence, respectively. Of the 570 animals examined, 13 $(2.3 \% ; 95 \%$ confidence interval $[\mathrm{CI}]=1.2 \%-3.8 \%)$ were seropositive for leishmaniasis, and $35(6.1 \%$; $95 \% \mathrm{CI}=4.3 \%-8.3 \%$ ) were seropositive for Chagas disease. A risk factor associated with seropositivity for Chagas disease in dogs was residence in a region with a predominance of small farms generally used for subsistence planting and leisure and surrounded by forest areas (odds ratio $=4.20$ ). By contrast, there were no risk factors identified for leishmaniasis, leading us to conclude that leishmaniasis and Chagas disease are present in dogs in the tourist city of Ibiúna, São Paulo; however, additional studies are needed in order to fully define the risk factors associated with disease in this municipality.
\end{abstract}

Key words: Dogs. Epidemiology. Leishmania spp. Southeastern Brazil. Trypanosoma.

\section{Resumo}

Médica Veterinária, Prefeitura Municipal de São Paulo, Secretaria da Saúde, Centro de Controle de Zoonoses, São Paulo, SP, Brasil. E-mail: mascolli@uol.com.br

2 Prof., Instituto Federal de Educação, Ciência e Tecnologia, Campus de São Roque, São Roque, SP, Brasil. E-mail: chicosoto34@ gmail.com

3 Profs., Programa de Pós-Graduação em Epidemiologia Experimental Aplicada às Zoonoses, Universidade de São Paulo, USP, São Paulo, SP, Brasil. E-mail: soniapin@usp.br; fumio@usp.br; savasco@usp.br

4 Discente do Curso de Doutorado do Programa de Pós-Graduação em Epidemiologia Experimental Aplicada às Zoonoses, USP, São Paulo, SP, Brasil. E-mail: gilguilloux@hotmail.com

5 Prof., Programa de Pós-Graduação em Medicina Veterinária, Universidade Federal de Campina Grande, UFCG, Patos, PB, Brasil. Email: sergio@vps.fmvz.usp.br

6 Prof ${ }^{a}$, Departamento de Clínica Cirurgia e Reprodução Animal, Universidade Estadual Paulista Júlio de Mesquita Filho, UNESP, Araçatuba, SP, Brasil. E-mail: mflima@fmvz.unesp.br

7 Prof., Faculdade de Medicina Veterinária e Zootecnia, UNESP, Botucatu, SP, Brasil. E-mail: hlangoni@fmvz.unesp.br

8 Discente do Curso de Doutorado do Programa de Pós-Graduação em Medicina Veterinária, UFCG, Patos, PB, Brasil. E-mail: anni.regina@gmail.com

* Author for correspondence 
O objetivo do trabalho foi determinar a soroprevalência de leishmaniose e doença de Chagas, e determinar os fatores de risco associados com a soropositividade em cães da Estância Turística de Ibiúna, Estado de São Paulo, Brasil. Foram colhidas amostras de sangue de 570 cães distribuídos em quatro regiões nos 48 bairros do município, no período de setembro de 2007 a março de 2008 e submetidas a exame sorológico. O diagnóstico laboratorial da leishmaniose e da doença de Chagas foi efetuado com o ensaio imunoenzimático (ELISA) indireto e com a reação de imunofluorescência indireta (RIFI), respectivamente. Dos 570 animais examinados, $13(2,3 \%$; IC 95\% $=1,2 \%-3,8 \%)$ foram soropositivos para leishmaniose, e $35(6,1 \%$; IC 95\% = 4,3\% - 8,3\%) para doença de Chagas. $\mathrm{O}$ animal ser procedente da região 4 (região com predomínio de pequenas propriedades rurais para plantio e lazer, circundadas por áreas de mata) $(\mathrm{OR}=4,20)$ foi a variável identificada como fator de risco associado à soropositividade para doença de Chagas, no entanto, não foram identificados fatores de risco para leishmaniose. Conclui-se que a leishmaniose e a doença de Chagas estão presentes em cães da Estância Turística de Ibiúna, São Paulo.

Palavras-chave: Cães. Epidemiologia. Leishmania sp. Sudeste do Brasil. Tripanossomíase.

\section{Introduction}

Visceral leishmaniasis (VL) and Chagas disease (CD; also known as American trypanosomiasis) are important parasitic zoonoses that affect domestic canids, their main urban reservoirs; these zoonoses require constant monitoring because of the close relationship of this species with humans.

VL, also known as kala azar, is a serious and systemic disease whose main species in Brazil is Leishmania (Leishmania) chagasi. It is transmitted by sand flies, especially the species Lutzomyia longipalpis. Its geographical distribution is worldwide, and it can be found in various regions of Brazil (FEITOSA et al., 2000; BRASIL, 2006).

VL has shown significant changes in the pattern of transmission, initially predominant in rural and peri-urban environments, but more recently in urban centers, such as Rio de Janeiro (RJ), Corumbá (MS), Belo Horizonte (MG), Aracatuba (SP), Palmas (TO), Três Lagoas (MS), Campo Grande (MS), and others. In São Paulo, the first human cases were recorded approximately in the year 2000, with an average of 184 cases per year by 2013. Currently in Brazil, VL is in 21 of the 27 states, with approximately 1,600 municipalities reporting autochthonous transmission (BRASIL, 2006, 2013).

Dogs are considered the main domestic reservoirs of $\mathrm{VL}$ and are central in maintaining the disease cycle (MELO, 2004). This is because the disease is more prevalent in dogs than it is in humans: human cases are usually preceded by canine cases because dogs have a higher amount of parasites in the skin than humans do, which favors infection by vectors (SANTA ROSA; OLIVEIRA, 1997; BANETH, 2006).

Trypanosomiasis in dogs is a problem in endemic regions reported in numerous studies that demonstrated infection in these areas (GÜRTLER et al., 1990, 1991, 1998; COHEN; GURTLER, 2001). Infection in dogs must be faced with concern, as dogs, as well as other mammals, may be Trypanosoma cruzi reservoirs to humans and other domestic animals, such as horses, cattle, sheep, and buffaloes. It is worth noting that natural infection in dogs with $T$. cruzi happens in the same way as in humans, i.e., through active transmission by vector, contamination by infected feces to the skin and/or conjunctiva, or the ingestion of vectors or infected tissues of wild animals present in the peridomicile or domicile (BARR, 2006).

Dogs can also carry the disease from endemic to non-endemic areas, creating new outbreaks (GÜRTLER et al., 2007). In Brazil, canine infection has been widely reported by Lucheis et al. (2005), Troncarelli et al. (2009), and Mendes et al. (2013). This confirms that the dog is an epidemiological link that maintains the interaction of wild and domestic transmission cycles, but few studies have been conducted in order to elucidate the importance of canine Chagas infection. 
Owing to the phylogenetic proximity between parasites and the fact that certain locations in South America are endemic for both diseases, it is important to conduct investigations where both diseases are investigated concurrently.

Because of the lack of information on the prevalence and risk factors for leishmaniasis and $\mathrm{CD}$ in the canine population of the tourist city of Ibiúna, São Paulo, Brazil, this study was designed in order to analyze the zoonotic potential of dogs in the municipality as reservoirs of the etiologic agents for both these zoonoses.

\section{Methods and Materials}

The municipality of Ibiúna is located in the southern region of São Paulo. It is one of the largest cities in the state, with a total of 1,093 square kilometers, which hinders the implementation of control measures on public health and on the canine population. An average altitude of 996 meters determines temperatures ranging from $6{ }^{\circ} \mathrm{C}$ to 27 ${ }^{\circ} \mathrm{C}$, with marked seasons: a cold and humid winter with temperatures between $4{ }^{\circ} \mathrm{C}$ and $14{ }^{\circ} \mathrm{C}$, and summer with temperatures varying between $16^{\circ} \mathrm{C}$ to $28{ }^{\circ} \mathrm{C}$, even reaching $35^{\circ} \mathrm{C}$ (IBGE, 2007).

Blood samples were collected randomly in the 48 districts of the municipality of IbiúnaSP, divided into four regions (1, 2, 3 and 4) that displayed different profiles: Region 1, consisted of mixed areas of recent urbanization without adequate infrastructure and disabled services, and rural areas composed of small farms; Region 2 was predominantly rural, formed by small farms and sites surrounded by forest areas; Region $3 \mathrm{had}$ urbanized areas with organized infrastructure; and Region 4 was predominantly composed of small farms surrounded by forest areas.

Samples were collected from September 2007 to March 2008, from a total of 570 animals. The sample size was based on the total population of dogs in the municipality, estimated at 16,065 animals using data of the human population by the Brazilian Institute of Geography and Statistics (IBGE), which reported
75,616 inhabitants for the year 2006. In order to calculate the dog/man ratio in urban areas, the World Health Organization recommends using the relationship 1:6 to 1:10 (WHO, 1990; REICHMANN et al., 1999); however, based on population estimates (SOTO et al., 2006) a 1:4 ratio was used. The sample size was calculated with an estimated prevalence of $1 \%$, and a $99 \%$ significance level. Sample collection was distributed over 48 districts of the municipality in proportion to the dog population and stratified by neighborhood, taking into account the estimated number of dogs in each region.

Blood samples were collected through a puncture of the radial cephalic vein, using 30x8 disposable needles and 10-mL disposable syringes. Blood samples were kept under refrigeration until arrival at the laboratory, where the serum was separated, centrifuged, and stored at $-20{ }^{\circ} \mathrm{C}$ until further use in serologic tests.

The owners of the dogs examined in the study were requested to answer an epidemiological questionnaire designed to provide information on key variables, including the absence or presence of practices and conditions that could act as potential risk factors for $\mathrm{VL}$ an, $\mathrm{CD}$. The variables and their categories were: gender (male, female), age $(\leq 2$ years, 2-6 years, $>6$ years), contact with mosquitoes (yes, no), presence of rats in the environment (yes, no), contact with areas of flooding (yes, no), handling (domesticated, semi-domesticated, loose), travel with the dog (yes, no), sexual activity (yes, no), and region of origin (Ibiúna-SP Region 1, 2, 3, or 4 , as described above).

Serology for canine visceral leishmaniasis (CVL) was conducted in the Zoonosis Diagnostic Laboratory, Faculty of Veterinary Medicine and Animal Science, São Paulo State University (UNESP), using the indirect enzyme-linked immunosorbent assay (ELISA). For detection, the Leishmania (L.) chagasi promastigotes total antigen and conjugated canine anti-IgG peroxidase were used at a dilution of 1:400 (LIMA et al., 2003). The reaction was read using a Titertek Multiskan Plus MK II microplate reader (Flow Laboratories International S.A., Lugano, Switzerland) at a 
wavelength of $492 \mathrm{~nm}$. The results were expressed as the mean optical density values from triplicates of each serum sample. The cutoff point was obtained by averaging the values obtained in canine negative controls from non-endemic areas for leishmaniasis. This value was derived from the mean plus three standard deviations of the optical density (OD) reading, considered 0.270 .

Antibodies to T. cruzi (REYES et al., 2002) were detected by indirect immunofluorescence test based on presence of the T. cruzi antigen (Y strain); samples were analyzed in serial dilutions of $1: 16$, 1:64, 1: 256, 1:1,024, and 1:4,096.

The data from epidemiological questionnaires were statistically analyzed in two stages-univariate analysis and multivariate analysis-to determine potential risk factors associated with seropositivity for leishmaniasis and $\mathrm{CD}$. In the univariate analysis, two groups of animals (seropositive and seronegative) were compared across the variables. Those variables with $\mathrm{p} \leq 0.2$ by chi-square test or Fisher's exact test were selected for multivariate analysis using multiple logistic regression analysis (HOSMER; LEMESHOW, 2000). The significance level was $5 \%$, and the analyses were performed with SPSS 20.0 for Windows.

\section{Results and Discussion}

Of the 570 dogs examined, 13 were seropositive for VL (Table 1), at a prevalence of $2.3 \%(95 \%$ confidence interval $[\mathrm{CI}]=1.2 \%-3.8 \%$ ). The prevalence by region ranged from $0.9 \%$ to $4.8 \%$; the highest concentration of positives was in Region 1 , with eight reagent dogs (4.8\%). The prevalence of VL in the canine population of Ibiúna, SP was lower than that previously reported by Azevedo et al. (2008) in Poxoréo, MT (7.8\%), by Silva and Braga (2008) in São Vicente Férrer, PE (12.3\%) or by Silva et al. (2008) in Brumadinho, MG (10.1\%). However, Martins (2008) and Barboza et al. (2009) reported VL frequencies of $1.9 \%$ (in Maceio, AL), and $0.7 \%$ (in Salvador), respectively, which are lower than our findings in the current study. According to
Ferrer (1999), the differences in prevalence of VL may be due to several factors, including the host immune response, the nature of the antigen used, sensitivity and specificity of serologic tests used, as well as the canine population studied. Rondon et al. (2008) proposed that the apparent divergence in data on the distribution and/or prevalence of VLC in Brazil suggests a seasonal variation that may be related to the peaks of abundance and reduction in the vector population.

The results of the univariate analysis of risk factors associated with VLC are shown in Table 2. No risk factors were identified after application of multiple logistic regression analysis, although some variables were noted. There was no significant difference in the prevalence of VLC in rural $(2.1 \%)$ and urban $(2.5 \%)$, a condition also observed in Rio Grande do Norte by Amora et al. (2006). These results can be explained by the process of disease urbanization in light of vector adaptation to urban environments, which would presumably result in a similar prevalence in both types of environments (MONTEIRO et al., 2005). However, Naveda et al. (2006) reported an uneven prevalence of $4.2 \%$ in rural areas and $1.1 \%$ in urban areas, suggesting that the risk factors for VL prevalence may be more complex compared to those identified in this study.

The urban environment provides a variety of conditions that favor the spread of the disease owing to the high density of dogs and the proximity of homes. On the other hand, the rural environment is favorable for vector proliferation, and supports the proximity of dogs with livestock as well as wild animals. The positive association between the prevalence of VL and the presence of these species in areas surrounding homes has already been shown (CABRERA et al., 2003). Barboza et al. (2006) found a significant association between the presence of pigs in areas surrounding homes and the risk of infection of dogs by L. chagasi. Moreira et al. (2003) have also reported a correlation between risk of infection and the presence of pigs and chickens, and Azevedo et al. (2008) reported a significant association between raising chickens 
and the seropositivity of dogs. Although there is no evidence that pigs and poultry are L. chagasi reservoirs, these species favor the breeding of sand flies, which in turn leads to increased risk of infection of dogs. In addition to attracting and retaining the vector as a source of nutrition, these animals provide the necessary environmental conditions of moisture and accumulation of organic matter that favor development of the larval stages of L. longipalpis (JULIÃO, 2004).

Table 1. Regional prevalence of leishmaniasis and Chagas disease in dogs in the municipality of Ibiúna, SP, from September 2007 to March 2008.

\begin{tabular}{cccccccc}
\hline \multirow{2}{*}{ Region } & \multirow{2}{*}{ Total No. of Animals } & \multicolumn{3}{c}{ Leishmaniasis } & \multicolumn{3}{c}{ Chagas Disease } \\
\cline { 2 - 7 } & & $\mathrm{N}$ & Prev. (\%) & $95 \%$ CI & $\mathrm{N}$ & Prev. (\%) & $95 \%$ CI \\
\hline 1 & 165 & 8 & 4.8 & $2.1-9.3$ & 9 & 5.4 & $2.5-10.1$ \\
2 & 145 & 2 & 1.4 & $0.2-4.9$ & 5 & 3.4 & $1.1-7.9$ \\
3 & 149 & 2 & 1.3 & $0.2-4.8$ & 8 & 5.4 & $2.3-10.3$ \\
4 & 111 & 1 & 0.9 & $0.02-4.9$ & 13 & 11.7 & $6.4-19.2$ \\
Total & 570 & 13 & 2.3 & $1.2-3.8$ & 35 & 6.1 & $4.3-8.3$ \\
\hline
\end{tabular}

Table 2. Univariate analysis of risk factors associated with leishmaniasis in dogs in the municipality of Ibiúna, SP, from September 2007 to March 2008.

\begin{tabular}{|c|c|c|c|c|}
\hline Variable & Category & $\begin{array}{l}\text { Total No. of } \\
\text { Dogs }\end{array}$ & $\begin{array}{c}\text { No. of positive Dogs } \\
(\%)\end{array}$ & $\mathrm{p}$ \\
\hline \multirow[t]{2}{*}{ Sex } & Male & 312 & $4(1.3)$ & \\
\hline & Female & 246 & $9(3.7)$ & $0.118^{*}$ \\
\hline \multirow[t]{3}{*}{ Age } & $\leq 2$ years & 116 & $4(3.4)$ & \\
\hline & 2 to 6 years & 304 & $5(1.6)$ & \\
\hline & $>6$ year & 139 & $4(2.9)$ & 0.484 \\
\hline \multirow[t]{2}{*}{ Contact with Mosquitoes } & No & 92 & $2(2.2)$ & \\
\hline & Yes & 451 & $11(2.4)$ & 1.000 \\
\hline \multirow[t]{2}{*}{ Presence of rats } & No & 43 & $0(0)$ & \\
\hline & Yes & 497 & $12(2.4)$ & 0.612 \\
\hline \multirow[t]{2}{*}{ Contact with areas of flooding } & No & 465 & $11(2.4)$ & \\
\hline & Yes & 71 & $1(1.4)$ & 1.000 \\
\hline \multirow[t]{3}{*}{ Handling } & Domesticated & 255 & $6(2.4)$ & \\
\hline & Semi-domesticated & 110 & $2(1.8)$ & \\
\hline & Loose & 191 & $5(2.6)$ & 0.907 \\
\hline \multirow[t]{2}{*}{ Travel with the Dog } & No & 518 & $11(2.1)$ & \\
\hline & Yes & 3 & $0(0)$ & 1.000 \\
\hline \multirow[t]{2}{*}{ Sexual activity (has bred) } & No & 201 & $6(3.0)$ & \\
\hline & Yes & 339 & $6(1.8)$ & 0.377 \\
\hline \multirow[t]{4}{*}{ Region of origin } & Region 1 & 165 & $8(4.8)$ & \\
\hline & Region 2 & 145 & $2(1.4)$ & \\
\hline & Region 3 & 149 & $2(1.3)$ & \\
\hline & Region 4 & 111 & $1(0.9)$ & $0.074 *$ \\
\hline
\end{tabular}

* Selected variables for multivariate analysis $(\mathrm{p} \leq 0.2)$. 
França-Silva et al. (2003) observed wide variations in the prevalence of VL in different districts of Montes Claros, MG, suggesting that specific ecosystems favor vector maintenance in distinct areas. Based on the results of the current study, this perspective can also be applied to Region 1, where most of the seropositive cases were concentrated, although a significant difference was not verified. The results suggest that this region should be regarded as a priority area for leishmaniasis research, so that the distribution and epidemiology of the disease can be clarified, particularly with regard to infection and vector control. According to Barcellos and Bastos (1996), understanding the geographical distribution of a disease can guide new efforts for planning and investment of funds in effective actions, which in the case of VL includes euthanasia of infected dogs, chemical vector control, as well as sanitary measures that are appropriate for the specific areas of risk.

Given the dog's social importance and traditional role as a pet, the indication that dogs that test positive should be euthanized must be considered based on evidence that limits the occurrence of false-positive reactions as much as possible. Euthanasia of dogs is not only costly and labor-intensive, but is also poorly received by the population (ALVES; BEVILACQUA, 2004). In light of this concern, positive and suspected reagent dogs in the present study would have been submitted to direct parasitological examination as an essential test to confirm infection before other measures may be considered.

ELISA has high sensitivity and specificity, and yields data that is in good agreement with the parasitological method (ZANETTE, 2006). Moreover, the ease of setup and reading of ELISA data makes it the preferred screening test in population surveys, in contrast to the standard cytological examination, which is associated with variability in sensitivity and difficulty of diagnosis (WOLSCHRIJN et al., 1996). However, false positive results may be obtained because of cross-reactivity with other agents such as Leishmania braziliensis (associated with cutaneous leishmaniasis) or Trypanosoma sp. (ZANETTE, 2006). Therefore, there is a need for improvement in the diagnostic techniques currently available, specifically with respect to sensitivity and specificity (ALVES; BEVILACQUA, 2004).

For CD, 35 dogs $(6.1 \%$; 95\% CI $=4.3 \%-8.3 \%)$ were seropositive for $T$. cruzi. The prevalence by region ranged from $3.4 \%$ to $11.7 \%$, consistent with a report by Reyes et al. (2002), who found a similar prevalence $(6.2 \%)$ in dogs from various municipalities of Costa Rica. However, lower positivity values were observed by Silva (2002) in Porto Alegre, RS (3.3\%), and by Troncarelli et al. (2009) in Botucatu, SP (4\%). In contrast, much higher levels of prevalence were found by Diosque et al. (2004) in the province of Chaco, Argentina (15.09\%), Gürtler et al. (1991) in Santiago del Estero, Argentina (39.8\%), Troncarelli et al. (2009) in Bauru, SP, with 40\%, and by Lucheis et al. (2005), who reported $86 \%$ seropositive dogs belonging to individuals with chronic Chagas in Botucatu, SP.

All 35 dogs that were seropositive for CD in the municipality of Ibiúna, SP, presented with antibody titers ranging from 20 to 40 . A low titer measurement may indicate the occurrence of cross-reactions with other trypanosomatides, such as Trypanosoma rangeli, a non-pathogenic agent (LUCHEIS et al., 2005), or other parasites. Findings by Gürtler et al. (1991) raised the possibility of antibody crossreactivity among agents of leishmaniasis, $\mathrm{CD}$, ehrlichiosis, babesiosis, and toxoplasmosis. Indeed, Troncarelli et al. (2009) reported cross-reactivity between Leishmania spp. and Trypanosoma cruzi. However, in the present study, no dog that was positive for leishmaniasis presented with $\mathrm{CD}$. Nevertheless, cross-reactions between infection with CD and infection by the Rickettsiaceae family of agents (which includes the genera Rickettsia sp. and Ehrlichia sp.) have been reported (FERREIRA et al., 2007).

As presented in Table 3, the following variables were considered in the univariate analysis: contact with ticks, presence of rats, and region of origin. The variable region of origin 4 (odds ratio $[\mathrm{OR}]=4.20$; 
$95 \% \mathrm{CI}=1.44$ to $12.27, \mathrm{p}=0.009)$ was identified as a risk factor in the final logistic regression model. Region 4 had the highest prevalence of CD $(13 / 111$, or $11.7 \%)$. The high prevalence observed in this region, which comprised rural districts, was expected, because rural areas are considered natural ecosystems of transmitting vectors. Regions 1 and 3 showed a similar prevalence of 5.4\%, a surprising result, as region 3 was composed exclusively of urban neighborhoods. Although Region 2 presented similar results, it comprised rural environments, and had the lowest prevalence among regions. Maywald et al. (1996) observed dogs in the municipalities of Triangulo Mineiro and Alto Paranaiba, MG, and suggested that other forms of transmission could be occurring (excluding contact with feces of 'barber bug'), partly due to the absence of $T$. cruzi triatomine vectors in domiciliary and peridomiciliary areas of homes with dogs that were positive for CD.

Table 3. Univariate analysis of risk factors associated with Chagas disease in dogs in the municipality of Ibiúna, SP, from September 2007 to March 2008.

\begin{tabular}{|c|c|c|c|c|}
\hline Variable & Category & $\begin{array}{l}\text { Total No. of } \\
\text { Dogs }\end{array}$ & $\begin{array}{l}\text { No. of positive } \\
\text { Dogs }(\%)\end{array}$ & $\mathrm{p}$ \\
\hline \multirow[t]{2}{*}{ Sex } & Male & 312 & $23(7.4)$ & \\
\hline & Female & 246 & $11(4.5)$ & 0.214 \\
\hline \multirow[t]{3}{*}{ Age } & $\leq 2$ years & 116 & $8(6.9)$ & \\
\hline & 2 to 6 years & 304 & $18(5.9)$ & \\
\hline & $>6$ year & 139 & $9(6.5)$ & 0.928 \\
\hline \multirow[t]{2}{*}{ Contact with Mosquitoes } & No & 345 & $16(4.6)$ & \\
\hline & Yes & 198 & $18(9.1)$ & $0.060 *$ \\
\hline \multirow[t]{2}{*}{ Presence of rats } & No & 43 & $0(0)$ & \\
\hline & Yes & 497 & $33(6.6)$ & $0.098^{*}$ \\
\hline \multirow[t]{2}{*}{ Contact with areas of flooding } & No & 465 & $31(6.7)$ & \\
\hline & Yes & 71 & $2(2.8)$ & 0.291 \\
\hline \multirow{3}{*}{ Handling } & Domesticated & 255 & $14(5.5)$ & \\
\hline & Semi-domesticated & 110 & $8(7.3)$ & \\
\hline & Loose & 191 & $11(5.8)$ & 0.797 \\
\hline \multirow[t]{2}{*}{ Travel with the Dog } & No & 518 & $30(5.8)$ & \\
\hline & Yes & 3 & $0(0)$ & 1.000 \\
\hline \multirow[t]{2}{*}{ Sexual activity (has bred) } & No & 201 & $10(5.0)$ & \\
\hline & Yes & 339 & $21(6.2)$ & 0.691 \\
\hline \multirow[t]{4}{*}{ Region of origin } & Region 1 & 165 & $9(5.5)$ & \\
\hline & Region 2 & 145 & $5(3.4)$ & \\
\hline & Region 3 & 149 & $8(5.4)$ & \\
\hline & Region 4 & 111 & $13(11.7)$ & $0.044 *$ \\
\hline
\end{tabular}

* Selected variables for multivariate analysis $(\mathrm{p} \leq 0.2)$. 


\section{Conclusion}

Serologic tests have shown that leishmaniasis and $\mathrm{CD}$ are present in dogs in the tourist city of Ibiúna, São Paulo, Brazil. However, there is a need for further studies to confirm the significance of dogs as reservoirs of infection by $T$. cruzi in this region.

\section{Acknowledgements}

The authors wish to thank Patrícia Viana (Federal University of Uberlândia) for conducting the statistical analysis, and Coordenação de Aperfeiçoamento de Pessoal de Nível Superior (CAPES) for the financial support.

\section{References}

ALVES, W. A.; BEVILACQUA, P. D. Reflexões sobre a qualidade do diagnóstico da leishmaniose visceral canina em inquéritos epidemiológicos: o caso da epidemia de Belo Horizonte, Minas Gerais, Brasil, 1993-1997. Cadernos de Saúde Pública, Rio de Janeiro, v. 20, n. 1, p. 259-265, 2004.

AMORA, S. S. A.; SANTOS, M. J. P.; ALVES, N. D.; COSTA, S. C. G.; CALABRESE, K. S.; MONTEIRO, A. J.; ROCHA, M. F. G. Fatores relacionados com a positividade de cães para leishmaniose visceral em área endêmica do Estado do Rio Grande do Norte, Brasil. Ciência Rural, Santa Maria, v. 36, n. 6, p. 1854-1859, 2006.

AZEVEDO, M. A.; DIAS, A. K. K.; PAULA, H. B.; PERRI, S. H. V.; NUNES, C. M. Avaliação da leishmaniose visceral canina em Poxoréo, Estado do Mato Grosso, Brasil. Revista Brasileira de Parasitologia Veterinária, Jaboticabal, v. 17, n. 3, p. 123-127, 2008.

BANETH, G. Leishmaniases. In: GREENE, C. E. Infectious diseases of the dog and cat. $3^{\text {th }}$ ed. Saint Louis: Saunders Elsevier, 2006. p. 685-698.

BARBOZA, D. C. P. M.; GOMES NETO, C. M. B.; LEAL, D. C.; BITTENCOURT, D. V. V.; CARNEIRO, A. J. B.; SOUZA, B. M. P. S.; OLIVEIRA, L. S.; JULIÃO, F. S.; SOUZA, V. M. M.; FRANKE, C. R. Estudo de coorte, em áreas de risco para leishmaniose visceral canina, em municípios da Região Metropolitana de Salvador, Bahia, Brasil. Revista Brasileira de Saúde e Produção Animal, Salvador, v. 7, n. 2, p. 152-163, 2006.
BARBOZA, D. C. P. M.; LEAL, D. C.; SOUZA, B. M. P. S.; CARNEIRO, A. J. B.; GOMES NETO, C. M. B.; ALCÂNTARA, A. C.; JULIÃO, F. S.; MOURA, S. A. B.; PERALVA, L. M. P.; FERREIRA, F.; FRANKE, C. R. Inquérito epidemiológico da leishmaniose visceral canina em três distritos sanitários do Município de Salvador, Bahia, Brasil. Revista Brasileira de Saúde e Produção Animal, Salvador, v. 10, n. 2, p. 434-447, 2009.

BARCELLOS, C.; BASTOS, F. I. Geoprocessamento, ambiente e saúde: uma união possível? Cadernos de Saúde Pública, Rio de Janeiro, v. 12, n. 3, p. 389-397, 1996.

BARR, S. C. American trypanosomiasis. In: GREENE, C. E. Infectious diseases of the dog and cat. $2^{\text {nd }} \mathrm{ed}$. Philadelphia: WB Saunders, 2006. p. 676-680.

BRASIL. Ministério da Saúde. Secretaria de Vigilância em Saúde. Departamento de Vigilância Epidemiológica. Manual de Vigilância e Controle da Leishmaniose Visceral. Brasília: Ministério da Saúde, 2006. 120 p.

Casos confirmados de Leishmaniose Visceral, Brasil, Grandes Regiões e Unidades Federadas 1990 a 2013. Brasília: Ministério da Saúde, 2013. Disponível em: <http://portalsaude. saude.gov.br/index.php/o-ministerio/principal/leiamais-o-ministerio/726-secretaria-svs/vigilanciade-a-a-z/leishmaniose-visceral-lv/11334-situacaoepidemiologica-dados>. Acesso em: 27 mar. 2015.

CABRERA, M. A. A.; PAULA, A. A.; CAMACHO, L. A. B.; MARZOCHI, M. C. A.; XAVIER, S. C.; SILVA, A. V. M.; JANSEN, A. M. Canine visceral leishmaniasis in Barra de Guaratiba, Rio de Janeiro, Brazil: assenssmente of risk factors. Revista do Instituto de Medicina Tropical de São Paulo, São Paulo, v. 45, n. 2, p. 79-83, 2003.

COHEN, J. E.; GURTLER, R. E. Modeling household transmission of American trypanossomiasis. Science, New York, v. 293, n. 5530, p. 694-698, 2001.

DIOSQUE, P.; PADILLA, A. M.; CIMINO, R. O.; CARDOZO, R. M.; NEGRETTE, O. S.; MARCO, J. D.; ZACCA, R.; MEZA, C.; JUAREZ, A.; ROJO, H.; REY, R.; CORRALES, R. M.; NASSER, J. R.; BASOMBRIO, M. A. Chagas disease in rural áreas of Chaco province, Argentina: epidemiologic survey in humans, reservoirs, and vectors. American Journal of Tropical Medicine and Hygiene, Oakbrook Terrace, v. 71, n. 5, p. 590-593, 2004.

FEITOSA, M. M.; IKEDA, F. A.; LUVIZOTTO, F. C. R.; PERRISH, V. Aspectos clínicos de cães com leishmaniose visceral no município de Araçatuba - São Paulo (Brasil). Revista Clínica Veterinária, São Paulo, v. 5, n. 28 , p. 36-43, 2000. 
FERREIRA, E. C.; LANA, M.; CARNEIRO, M.; REIS, A. B.; PAES, D. V.; SILVA, E. S.; SCHALLIG, H.; GONTIJO, C. M. F. Comparison of serological assays for the diagnosis of canine visceral leishmaniasis in animals presenting diferente clinical manifestations. Veterinary Parasitology, Amsterdam, v. 146, n. 3-4, p. 235-241, 2007.

FERRER, L. M. Clinical aspects of canine leishmaniasis. In: INTERNATIONAL CANINE LEISHMANIAIS FORUM, 1999, Barcelona. Proceedings... Barcelona: Intervet International, 1999. p. 6-10.

FRANÇA-SILVA, J. C.; COSTA, R. T.; SIQUEIRA, A. M.; MACHADO-COELHO, G. L. L.; COSTA, C. A.; MAYRINK, W.; VIEIRA, E. P.; COSTA, J. S.; GENARO, O.; NASCIMENTO, E. Epidemiology of canine visceral leishmaniasis in the endemic area of Montes Claros municipality, Minas Gerais State, Brazil. Veterinary Parasitology, Amsterdam, v. 111, n. 2-3, p. 161-173, 2003.

GÜRTLER, R. E.; CECERE, M. C.; LAURICELLA, M. A.; CARDINAL, M. V.; KITRON, U.; COHEN, J. E. Domestic dogs and cats as sources of Trypanosoma cruzi infection in rural northwestern Argentina. Parasitology, Cambridge, v. 134, n. 1, p. 69-82, 2007.

GÜRTLER, R. E.; CÉCERE, M. C.; RUBEL, D. N.; PETERSEN, R. M.; SCHWEIGMANN, N. J.; LAURICELLA, M. A.; BUJAS, M. A.; SEGURA, E. L.; WISNIVESKY-COLLI, C. Chagas disease in north-west Argentina: infected dogs as a risk fator for the domestic transmission of Trypanossoma cruzi. American Journal of Tropical Medicine and Hygiene, Oakbrook Terrace, v. 85, n. 6, p. 741-745, 1991.

GÜRTLER, R. E.; CHUIT, R.; CECERE, M. C.; CASTANERA, M. B.; COHEN, J. E.; SEGURA, E. L. Prevalence of seropositivity for Trypanossoma cruzi in three rural villages in northwest Argentina: environmental, demographic, and entomologic associations. American Journal of Tropical Medicine and Hygiene, Oakbrook Terrace, v. 59, n. 5, p. 741-749, 1998.

GÜRTLER, R. E.; KRAVETZ, F. O.; PETERSEN, R. M. The prevalence of Trypanossoma cruzi infection and the demography of dog populations after inseticidal spraying of houses: a predictive model. Annals of Tropical Medicine and Parasitology, New York, v. 84, n. 4, p. 313-323, 1990.

HOSMER, D. W.; LEMESHOW, S. Applied logistic regression. New York: John Wiley \& Sons, 2000. 373 p.

INSTITUTO BRASILEIRO DE GEOGRAFIA E ESTATÍSTICA - IBGE. IBGE Cidades: Ibiúna:
IBGE, 2007. Disponível em: <http://www.ibge.gov.br/ cidadesat/>. Acesso em: 20 set. 2007.

JULIÃO, F. S. Estudo epidemiológico de focos de leishmaniose visceral canina na Região Metropolitana de Salvador, Bahia, Brasil. 2004. Dissertação (Mestrado em Medicina Veterinária Tropical) - Universidade Federal da Bahia, Salvador.

LIMA, V. M. F.; GONÇALVES, M. E.; IKEDA, F. A.; LUVIZOTTO, M. C. R.; FEITOSA, M. M. Antileishmania antibodies in cerebrospinal fluid from dogs with visceral leishmaniasis. Brazilian Journal of Medical and Biological Research, Ribeirão Preto, v. 36, n. 4, p. 485-489, 2003.

LUCHEIS, S. B.; SILVA, A. V. da; ARAÚJO JUNIOR, J. P.; LANGONI, H.; MEIRA, D. A.; MARCONDESMACHADO, J. Trypanosomatids in dogs belonging to individuals with cronic Chagas disease living in Botucatu town and surrounding region, São Paulo State, Brazil. Journal of Venomous Animals and Toxins including Tropical Diseases, Botucatu, v. 11, n. 4, p. 492-509, 2005.

MARTINS, I. V. Aspectos epidemiológicos e de hemostasia na leishmaniose visceral canina. 2008. Dissertação (Mestrado em Ciência Veterinária) Universidade Federal Rural de Pernambuco, Recife.

MAYWALD, P. G.; MACHADO, M. I.; COSTA-CRUZ, J. M.; GONÇALVES-PIRES, M. R. F. Leishmaniose tegumentar, visceral e doença de Chagas caninas em municípios do Triangulo Mineiro e Alto Paranaíba, Minas Gerais, Brasil. Cadernos de Saúde Pública, Rio de Janeiro, v. 12, n. 3, p. 321-328, 1996.

MELO, M. N. Leishmaniose visceral no Brasil: desafios e perspectivas. Revista Brasileira de Parasitologia Veterinária, Jaboticabal, v. 13, p. 41-45, 2004. Suplemento 1.

MENDES, R. S.; SANTANA, V. L.; JANSEN, A. M.; XAVIER, S. C. C.; VIDAL, I. F.; ROTONDANO, T. E. F.; SOUZA, A. P. Aspectos epidemiológicos da Doença de Chagas canina no semiárido Paraibano. Pesquisa Veterinária Brasileira, Rio de Janeiro, v. 33, n. 12, p. 1459-1465, 2013.

MONTEIRO, E. M.; SILVA, J. C. F.; COSTA, R. T.; COSTA, D. C.; BARATA, R. A.; PAULA, E. V.; MACHADO-COELHO, G. L. L.; ROCHA, M. F.; FORTES-DIAS, C. L.; DIAS, E. S. Leishmaniose visceral: estudo de flebotomíneos e infecção canina em Montes Claros, Minas Gerais. Revista da Sociedade Brasileira de Medicina Tropical, Uberaba, v. 38, n. 2, p. 147-152, 2005. 
MOREIRA, J. R. E. D.; SOUZA, V. M. M.; SREENIVASAN, M.; LOPES, N. L.; BARRETO, R. B.; CARVALHO, L. P. Peridomestic risk factors for canine leishmaniasis in urban dwellings: new findings from a prospective study in Brazil. American Journal of Tropical Medicine and Hygiene, Oakbrook Terrace, v. 69, n. 4, p. 393-397, 2003.

NAVEDA, L. A. B.; MOREIRA, E. C.; MACHADO, J. G.; MORAES, J. R. C.; MARCELINO, A. P. Aspectos epidemiológicos da leishmaniose visceral canina no município de Pedro Leopoldo, Minas Gerais, 2003. Arquivo Brasileiro de Medicina Veterinária e Zootecnia, Belo Horizonte, v. 58, n. 6, p. 988-993, 2006.

REICHMANN, M. L. A. B.; PINTO, H. B. F.; NUNES, V. P. Vacinação contra raiva de cães e gatos. São Paulo: Instituto Pasteur, 1999. 32 p.

REYES, L.; SILESKY, E.; CERDAS, C.; CHINCHILLA, M.; GUERRERO, O. Presencia de anticuerpos contra Trypanossoma cruzi em perros de Costa Rica. Parasitologia Latino-Americana, Santiago, v. 57, n. 1-2, p. 66-68, 2002.

RONDON, F. C. M.; BEVILAQUA, C. M. L.; FRANKE, C. R.; BARROS, R. S.; OLIVEIRA, F. R.; ALCÂNTARA, A. C.; DINIZ, A. T. Cross-sectional serological study of canine Leishmania infection in Fortaleza, Ceará State, Brazil. Veterinary Parasitology, Amsterdam, v. 155, n. 1-2, p. 24-31, 2008.

SANTA ROSA, I. C. A.; OLIVEIRA, I. C. S. Leishmaniose visceral: breve revisão sobre uma zoonose reemergente. Revista Clínica Veterinária, São Paulo, v. 2, n. 11, p. 24-28, 1997.

SILVA, D. C. B.; SILVA, D. C. B.; FREIRE, J. M.; OLIVEIRA, R. J.; DIAS, N. L. Aspectos epidemiológicos da leishmaniose visceral canina no município de Brumadinho, Minas Gerais. In: CONGRESSO BRASILEIRO DE MEDICINA VETERINÁRIA, 35., 2008, Gramado. Anais... Gramado: Sociedade de Veterinária do Rio Grande do Sul, 2008. p. 5.
SILVA, L. S. Prevalência de soropositivos para a doença de Chagas em uma amostra da população de cães domiciliados da cidade de Porto Alegre. 2002. Dissertação (Mestrado em Ciência da Saúde Cardiológica e Ciências Cardiovasculares) - Programa de PósGraduação em Ciência da Saúde Cardiológica e Ciências Cardiovasculares. Universidade Federal do Rio Grande do Sul, Porto Alegre.

SILVA, O. A.; BRAGA, G. M. S. Leishmaniose visceral canina no município de São Vicente Férrer, Estado de Pernambuco, Brasil. Revista Brasileira de Ciência Veterinária, Niterói, v. 15, n. 2, p. 101-102, 2008.

SOTO, F. R. M.; FERREIRA, F.; PINHEIRO, S. R.; NOGARI, F.; RISSETO, M. R.; SOUZA, O.; AMAKU, M. Dinâmica populacional canina no Município de Ibiúna - SP: estudo retrospectivo. Brazilian Journal of Veterinary Research and Animal Science, São Paulo, v. 43, n. 2, p. 178-185, 2006.

TRONCARELLI, M. Z.; CAMARGO, J. B.; MACHADO, J. G.; LUCHEIS, S. B.; LANGONI, H. Leishmania spp. and/or Trypanosoma cruzi diagnosis in dogs from endemic and nonendemic areas for canine visceral leishmaniasis. Veterinary Parasitology, Amsterdam, v. 164, n. 2-4, p. 118-123, 2009.

WOLSCHRIJN, C. F.; MEYER, H. P.; HAZEWINKEL, H. A.; WOLVEKAMP, W. T. Destructive polyarthritis in a dog with leishmaniasis. Journal of Small Animal Practice, Malden, v. 37, n. 12, p. 601-603, 1996.

WORLD HEALTH ORGANIZATION - WHO. Guidelines for dog population management. Geneva: WHO, 1990.

ZANETTE, M. F. Comparação entre os métodos de ELISA, imunofluorescência indireta e imunocromatografia para o diagnóstico de leishmaniose visceral canina. 2006. Dissertação (Mestrado em Ciência Animal) - Faculdade de Medicina Veterinária. Universidade Estadual Paulista Júlio de Mesquita Filho, Araçatuba. 